\title{
Prognostic Value of Mean Platelet Volume and Platelet to Lymphocyte Ratio in Laryngeal Carcinoma
}

\author{
Beyhan Yılmaz ${ }^{1}$, Engin Şengüll, Murat Şereflican ${ }^{2}$, Musa Özbay ${ }^{1}$, Vefa Kınıs ${ }^{1}$, Aylin Gül ${ }^{1}$, \\ Fatma Teke ${ }^{3}$ İsmail Topçu ${ }^{1}$
}

\section{ABSTRACT}

Objective: In this study, we aimed to investigate whether platelet lymphocyte ratio (PLR) and Mean platelet volume (MPV) values can be used as prognostic and diagnostic markers in laryngeal cancer.

Methods: A total of 242 patients with laryngeal pathology were reviewed retrospectively. PLR, MPV and platelet values were compared in patients with benign and malignant pathologies. The correlation of PLR, MPV and platelet values of patients with malignant pathologies with their age, gender, smoking, alcohol use, degree of differentiation, and clinical stage was investigated.

Results: The PLR values were significantly higher in smokers $(p=0.009)$, alcohol drinkers $(p=0.001)$, clinical stage IV patients $(p=0.001)$, and patients with poor differentiated laryngeal cancer $(p=0.001)$, compared to nonsmokers, nonalcohol consumers, clinical stage III patients, and patients with well-differentiated laryngeal cancer. MPV values were significantly lower in patients with clinical stage IV $(p=0.018)$, and poor differentiated $(p=0.010)$, laryngeal cancer compared to patients with clinical stage III and well-differentiated laryngeal cancer. The PLR value was significantly higher in the malignant group than in the benign group $(p<0.001)$.

Conclusion: Our results showed that PLR values can be used as diagnostic and prognostic factors and MPV values can be used as prognostic factors in laryngeal cancer. J Clin Exp Invest 2016; 7 (2): 134-138

Key words: Platelet-lymphocyte ratio, mean platelet volume, prognostic marker, diagnostic marker, laryngeal carcinoma

\section{Larenks Karsinomunda Ortalama Trombosit Hacmi ve Trombosit-Lenfosit Oranının Prognostik Değeri}

\section{ÖZET}

Amaç: Bu çalışmada larenks karsinomunda trombosit-lenfosit oranı (PLR) ve ortalama trombosit hacmi (MPV) değerlerinin prognostik ve diagnostik marker olarak kullanılıp kullanılamayacağının araştıııması amaçlanmıştır.

Yöntemler: Larengeal patolojisi olan 242 hastanın verileri retrospektif olarak incelenmiştir. PLR, MPV ve platelet değerleri benign ve malign patolojiye sahip hastalar arasında karşılaştıııımıştır. Malign patolojili hastaların PLR, MPV ve platelet değerleri ile yaş, cinsiyet, sigara, alkol kullanımı, klinik evre ve diferansiasyon dereceleri arasındaki korelasyona bakılmıştır.

Bulgular: PLR değerleri; sigara içenlerde içmeyenlere göre $(p=0,009)$, alkol kullananlarda kullanmayanlara göre $(p=0,001)$, klinik evresi IV olan hastalarda klinik evresi III olan hastalara göre $(p=0,001)$, kötü diferansiye hastalarda iyi diferansiye hastalara göre $(p=0,001)$ anlamlı olarak daha yüksek bulunmuştur. MPV değerleri ise; klinik evre IV hastalarda klinik evre III hastalara göre $(p=0,018)$, kötü diferansiye hastalarda iyi diferansiye hastalara göre $(p=0,010)$ anlamlı olarak daha düşük izlenmiş̧tir. PLR değerleri malign grupta benign gruba göre anlamlı olarak daha yüksek bulunmuştur $(p<0,001)$.

Sonuç: Sonuçlarımız, PLR değerinin larenks karsinomunda prognostik ve diagnostik marker olarak, MPV değerinin ise prognostik marker olarak kullanılabileceğini göstermiştir.

Anahtar kelimeler: Trombosit-lenfosit oranı, ortalama trombosit hacmi, prognostik marker, diagnostik marker, larengeal karsinom

${ }^{1}$ Department of Otorhinolaryngology, Dicle University Medical Faculty, Diyarbakir, Turkey

${ }^{2}$ Department of Otorhinolaryngology, Abant Izzet Baysal University Medical Faculty, Bolu, Turkey

${ }^{3}$ Department of Radiation Oncology, Dicle University Medical Faculty, Diyarbakir, Turkey

Correspondence: Beyhan Yilmaz,

Department of Otorhinolaryngology, Dicle University, Medical Faculty, Diyarbakir, Turkey Email: drbeyhanyilmaz@gmail.com Received: 04.04.2016, Accepted: 25.04.2016

Copyright (C) JCEI / Journal of Clinical and Experimental Investigations 2016, All rights reserved 


\section{INTRODUCTION}

Two-five percent of all cancers and $45 \%$ of head and neck cancers are laryngeal cancer [1]. Multiple factors such as alcohol, smoking, heredity, hormones, pollution, asbestos, wood dust, coal, various metals, viral infections and diet are responsible for etiology [2].

Prognostic factors such as gender, age, stage of the disease, invasion of the thyroid cartilage, good surgical margins, as well as alcohol and tobacco consumption are routinely used for predicting progression of laryngeal cancer. In addition, essential information regarding the prognosis can be obtained from histopathological examination. Some of the main histopathological prognostic factors for indication of laryngeal neoplasms are inflammatory reactions, degree of cell differentiation, and small blood vessels invasion by cells [3].

Due to insufficient number of currently used prognostic factors, the latest focus of cancer research is related to development of new prognostic factors. The link between cancer and inflammation was recognized as early as the beginning of 19th century, however its role in cancer's progression as well as pathogenesis is only validated in the last few decades [4]. Thus various inflammatory cells have come into question to act as prognostic factors in cancer.

It is known that neutrophils and lymphocytes are responsible for inflammation. Recent studies reported that platelets play a major role in inflammation. The close relationship between platelets and cancer let to derived platelets biomarkers for cancer prognosis. Mean platelet volume (MPV) is an indicator of increased platelet activation and can easily be detected from the peripheral blood through complete blood count analysis [5]. Platelet lymphocyte ratio (PLR) is another parameter that can be determined through complete blood count analysis by dividing the platelet count by lymphocyte count. Studies have shown that derived thrombocytes biomarkers can be prognostic factors in cancers where inflammation is held responsible for the pathogenesis. For example, MPV values have been used as prognostic factors in hepatocellular carcinoma [6], ovarian cancer [7], colon cancer [8] and lung cancer [9]. PRL values have also been identified as a reliable and easy to use prognostic factor in cancers such as ovarian [10], colorectal [11], breast [12] and non-small cell lung cancer [13]. To our knowledge there are no studies that investigate the roles of PLR and MPV values as prognostic factors in laryngeal cancer.
In this study we aimed to investigate the feasibility of PLR and MPV values as indicators of prognosis in laryngeal cancer. We will compare PLR and MPV values with prognostic factors such as degree of differentiation, clinical stage of the disease, age, sex, as well as tobacco and alcohol consumption. Lastly, patients with benign and malignant laryngeal pathologies will be compared in terms of PLR and MPV values.

\section{METHODS}

The study included results of 242 patients with laryngeal pathologies. These patients underwent biopsies by using direct laryngoscopy at Abant İzzet Baysal University and Dicle University Faculty of Medicine, Ear, Nose and Throat clinics between January 2005 and December 2016. The patients' clinical and laboratory results were retrospectively screened from the ENT archive files. Pathology results were retrospectively reviewed from the pathology archives.

The demographic data as well as consumption of alcohol and tobacco use were recorded. The preoperative platelet (PLT), lymphocyte (LYMP), MPV, and neutrophil (NEU) values were recorded from the routine laboratory tests.

Based on pathologies, the patients were divided into two groups. The first group contained patients with benign pathologies, while the second group contained patients with malignant pathologies. The benign pathology group included nodules, polyps, papilloma, ulcer, hematoma, seborrheic keratosis and pyogenic granuloma diagnoses and consisted entirely of squamous cell carcinoma. Furthermore, based on the degree of cell differentiation, additional three subgroups were established in the malignant pathology group: well-differentiated malignancies, moderately differentiated malignancies and poorly differentiated malignancies. The 2002 American Joint Committee on Cancer (AJCC) staging system was used for the clinical staging. Most laryngeal carcinoma patients in our study were either stage III or stage IV.

PLR was obtained by dividing the platelet count by the lymphocyte count. The correlation between PLR, MPV, NEU, LYMP and PLT values and factors such as consumption of alcohol and tobacco, degree of differentiation and clinical stage of the disease and patient's age, and gender was investigated. Patients with malignant laryngeal pathologies were compared to the ones with benign pathologies in terms of PLR, MPV, NEU, LYMP and PLT values. 
The SPSS 15.0 software program was used to analyze data. The frequency distributions and means were assessed. Moreover, the normalcy of distribution between the groups was examined. While the normally distributed data was assessed with one-way ANOVA and Student's t-tests; the non-normally distributed data was assessed by using Mann Whitney U and Kruskal-Wallis tests. The $\mathrm{p}$ value of $<0.05$ was accepted as statistically significant.

The department's local ethics committee approved the study. The study was conducted in compliance with the 2013 amendment of the declaration of Helsinki.

\section{RESULTS}

The demographic characteristics of all the patients are given in Table 1. The PLR, MPV and PLT values of patients with benign and malignant pathologies were compared. The malignant group had a significantly higher PLR values compared to the benign group. In contrast, both groups had similar MPV and PLT values (Table 1).

Table 1. Comparison of values between benign and malign pathology groups

\begin{tabular}{|c|c|c|c|}
\hline Variable & Benign Pathology & Malign pathology & p value \\
\hline Patients & 101 & 141 & \\
\hline $\begin{array}{l}\text { Age (Mean } \pm S D) \text {, } \\
\text { years }\end{array}$ & $48.18 \pm 14.20$ & $64,46 \pm 11.06$ & $<0.001$ \\
\hline \multicolumn{4}{|l|}{ Sex } \\
\hline Male & 92 (\% 65.2) & 96 (\%95) & $<0.001$ \\
\hline Female & 49 (\% 34.8) & $5(\% 5)$ & \\
\hline PLR (Mean) & 113.34 & 196.47 & $<0.001$ \\
\hline MPV, fl, (Mean) & 8.34 & 8.35 & 0.138 \\
\hline PLT, $x 10^{3} / \mu \mathrm{l}$ (Mean) & 262.41 & 259.85 & 0.194 \\
\hline
\end{tabular}

PLR: Platelet to lymphocyte ratio, MPV: Mean platelet volume, PLT: Platelet number, SD: Standard deviation

The clinicopathological findings of patients with malignant pathologies are shown in Table 2. The correlation of PLR and MPV values of patients with malignant pathologies with clinical stage of the disease, degree of differentiation, alcohol and tobacco consumption, gender and age were investigated. The PLR values were positive correlated with clinical stage, degree of differentiation smoking, and alcohol use. The PLR values were significantly higher in smokers, alcohol drinkers, clinical stage III patients, and patients with poor differentiated laryngeal cancer compared to nonsmokers, non alcohol consumers, clinical stage IV patients, and patients with well-differentiation laryngeal cancer. In contrast, gender and age was not significantly correlated.

There was a negative correlation of MPV with the diseases' degree of differentiation and clinical stage. The patients with poor differentiated stage IV laryngeal cancer had significantly lower MPV values compared to the ones with well-differentiated stage III laryngeal cancer. No significant relationship was observed between age, gender, smoking, and alcohol consumption (Table 2).

Table 2. Relation of Prognostic Factors with platelet to lymphocyte ratio, mean platelet volume, platelet numbers

\begin{tabular}{lcccc}
\hline Variable & $\begin{array}{c}\text { Patients } \\
\mathbf{n}(\%)\end{array}$ & $\begin{array}{c}\text { PLR } \\
\text { (Mean) }\end{array}$ & $\begin{array}{c}\text { MPV } \\
\text { (Mean) }\end{array}$ & $\begin{array}{c}\text { PLT } \\
\text { (Mean) }\end{array}$ \\
\hline Age & & & & \\
$\quad 65 \geq$ & $50(49.5)$ & 192.27 & 8.45 & 257.36 \\
$\quad 65<$ & $51(50.5)$ & 200.59 & 8.26 & 262.29 \\
$\quad p$-value & & 0.781 & 0.773 & 0.689 \\
\hline Sex & & & & \\
$\quad$ Male & $96(95)$ & 153,15 & 8.34 & 256.96 \\
$\quad$ Female & $5(5)$ & 130,24 & 8.35 & 276.61 \\
$\quad p$-value & & 0,127 & 0.445 & 0.044 \\
\hline
\end{tabular}

Smoking

Yes

$\begin{array}{lllll}\text { No } & 79(78.2) & 210.03 & 8.37 & 259.22\end{array}$

\begin{tabular}{ccccc}
$p$-value & $22(21.8)$ & 147.80 & 8.30 & 262.14 \\
\hline Alcohol & & $\mathbf{0 . 0 0 9}$ & 0.799 & 0.684 \\
Yes & $54(53.4)$ & 245.81 & 8.23 & 277.57 \\
No & $47(46.6)$ & 139.78 & 8.49 & 239.49 \\
$p$-value & & $\mathbf{0 . 0 0 1}$ & 0.086 & 0.052
\end{tabular}

Histological Grade

$\begin{array}{lllll}\text { G1 } & 37(36.6) & 155.15 & 9.03 & 249.16 \\ \text { G2 } & 44(43.5) & 186.29 & 8.22 & 251.55 \\ \text { G3 } & 20(20.0) & 295.34 & 8.34 & 265.90\end{array}$

$p$-value

\begin{tabular}{llll} 
G1-G2 & $0.027^{a}$ & $0.054^{a}$ & $0.420^{a}$ \\
\hline G2-G3 & $0.031^{b}$ & $0.050^{b}$ & $0.025^{b}$ \\
\hline G1-G3 & $0.001^{c}$ & $0.010^{c}$ & $0.002^{c}$
\end{tabular}

\begin{tabular}{lcccc}
\hline Clinical TNM stage & & & & \\
\hline Stage III & $44(43.5)$ & 141.36 & 8.80 & 240.36 \\
\hline Stage IV & $57(56.5)$ & 239.02 & 8.00 & 274.84 \\
p- value & & 0.001 & 0.018 & 0.017 \\
\hline
\end{tabular}

PLR: Platelet to lymphocyte ratio, MPV: Mean platelet volume, PLT: Platelet number, G1: Well-differentiated G2: Moderately differentiated G3: Poorly differentiated

a Shows the difference between the G1-G2 group; ${ }^{b}$ Shows the difference between the G2-G3 group; c Shows the difference between the G1-G3 group 


\section{DISCUSSION}

Platelets are essential and multifunctional in cancer development [14]. Firstly, platelets facilitate metastasis [15]. It is believed that during hematogenous spreading, platelets supports the life of circulating tumor cells and enhances the retention of tumor cell emboli in microcirculation [16,17]. Secondly, platelets stimulate a boost in megakaryocytes and pro-inflammatory cytokines (interleukin 1, 3 and 6) released by cancer as well as accumulation of thrombocytosis [18]. Biomarkers derived from platelets are important due to the close relationship between platelets and cancer. Increased MPV and PLR values in peripheral blood have been identified as prognostic factors in cancer types such as hepatocellular carcinoma, ovarian cancer, colon cancer and gastric cancer [6-13]. In contrast, the feasibility of using platelets as indicators of prognosis in laryngeal cancer was not investigated in any of the studies. This study is the first to assess effectiveness of MPV and PLR levels as prognostic factors for laryngeal cancer.

Several reports have shown that increased MPV values are associated with the prognosis of various cancers [6-9]. Cho et al. [6] reported that patients with hepatocellular carcinoma had higher MPV and MPV/ PC values compared to those in the control group. Moreover, Kemal et al. [7] found that patients with epithelial ovarian cancer had significantly higher NLR, MPV and PLR values than those in the control group. Osada et al. [9] also found that patients with stomach cancer had higher MPV values compared to the individuals in the control group.

However, some studies reported that low MPV values were associated with the prognosis of various cancers. For example, Noriko and et al. [19] determined that patients with advanced stage non-small-cell lung cancer had significantly lower MPV and MPV/ PC values then control individuals. Moreover, Shogo et al. [20] identified that low MPV levels in patients with resected non-small-cell lung cancer were associated with poor prognosis. Öncel et al. [21] compared lung cancer patients with a control group and determined that MPV and plateletcrit values were lower in patients with lung cancer, while PLT, platelet distribution width, and platelet count values were similar in both groups. Mutlu et al. [22] evaluated MPV values at two different stages i.e. at the time of the cancer diagnosis and during the thromboembolic events in patients with various cancer types.. They found that MPV values during the thromboembolic events were significantly lower compared to MPV values at the time of the diagnosis. In addition, Aksoy et al. [23] reported that patients with bone marrow metastasis had significantly lower MPV values than individuals in the control group.

Our study results are similar with other studies suggesting that low MPV values are good prognostic factors. We found a significant negative correlation between MPV and the degree of differentiation. Less differentiated laryngeal cancer had significantly lower MPV values than well-differentiated laryngeal cancer. Moreover, patients with stages IV laryngeal cancer had significantly lower MPV values compared to patients with stage III laryngeal cancer. Based on these findings, we suggest that low MPV values can be used as an indicator of poor prognosis for laryngeal cancer.

The value of increased PLT as a prognostic factor in various cancers is diverse [10-13]. Asher et al. [10] reported that patients with ovarian cancer had higher PLR and NLR values than those in the control group leading to the conclusion that PLR and NLR values can be used as prognostic factors. Similarly, Kwon et al. [11] also suggested using NLR and PLR values as prognostic factors since patients with operable colorectal cancer had higher NLR and PLR values than individuals in the control group. Lastly, a study by Krenn-Pilko et al. [12] reported that PLR values were increased in patients with breast cancer.

In our study, PLR levels were significantly higher in patients with poorly differentiated, stage IV laryngeal cancer that smoker and consumed alcohol compared to patients with well or moderately differentiated, stage III laryngeal cancer that smoked and use alcohol. Thus we suggested that increased PLR levels could be used as a marker for poor prognosis in laryngeal cancer.

The second objective of our study was to determine the efficacy of using PLR and MPV values as diagnostic markers in laryngeal cancer. For this purpose, we compared the PLR and MPV values between benign and malignant laryngeal pathologies. One study [24] assessed the role of MPV as a diagnostic marker in head and neck cancers. However, to the best of our knowledge, there are no studies regarding the diagnostic role of PLR. Eryllmaz et al. [24] reported that patients with head and neck cancers had higher MPV values than those in the control group, suggested that MPV can be used as a diagnostic marker. Our study did not found a significant difference in MPV values between the patients with malignant and benign pa- 
thologies. In contrast, patients with laryngeal cancer had significantly elevated PLR values than those with benign pathologies. These results suggested that PLR can be used as a diagnostic marker in laryngeal cancer. These findings can help in predicting whether the lesions are benign or malignant during the preoperative stage in patients scheduled for surgery due to laryngeal pathology. We believe that high PLR values can indicate the malignant pathology.

In conclusion, our results suggest that PLT values are effective prognostic and diagnostic factors in patients with laryngeal cancer. However, overall survival and disease-free survival of our patients couldn't be evaluated due to difficulties in the postoperative follow-ups. Therefore, prospective and multicenter studies are needed to corroborate these results.

Declaration of Conflicting Interests: The authors declare that they have no conflict of interest.

Financial Disclosure: No financial support was received.

\section{REFERENCES}

1. Lin HW, Bhattacharyya N. Staging and survival analysis for nonsquamous cell carcinomas of the larynx. Laryngoscope. 2008;118:1003-13.

2. Hashibe M, Boffetta P, Zaridze D, et al. Contribution of tobacco and alcohol to the high rates of squamous cell carcinoma of the supraglottis and glottis in Central Europe. Am J Epidemiol. 2007;165:814-20.

3. Iovănescu GH, Poenaru M, Doroş C, Borugă O. Histopathological prognostic and risk factors in patients with laryngeal neoplasms. Rom J Morphol Embryol. 2013;54:1087-92.

4. Balkwill F. \& Mantovani A. Inflammation and cancer: back to Virchow? Lancet. 2001;357:539-45.

5. Tozkoparan E, Deniz O, Ucar E, et al. Changes in platelet count and indices in pulmonary tuberculosis. Clin Chem Lab Med. 2007;45:1009-13.

6. Cho SY, Yang JJ, You E, et al. Mean platelet volume/platelet count ratio in hepatocellular carcinoma. Platelets. 2013;24:375-7.

7. Kemal Y, Demirag G, Ekiz K. and Yucel I: Mean platelet volume could be a useful biomarker for monitoring epithelial ovarian cancer. J Obstet Gynaecol. 2014;34:515-8.
8. Osada J, Rusak M, Kamocki Z, et al. Platelet activationin patients with advanced gastric cancer. Neoplasma. 2010;57:145-50.

9. Asher V, Lee J, Innamaa A, Bali A. Preoperative platelet lymphocyte ratio as an independent prognostic marker in ovarian cancer. Clin Transl Oncol. 2011;13:499-503.

10. Kwon HC, Kim SH, Oh SY, et al. Clinical significance of preoperative neutrophil-lymphocyte versus platelet-lymphocyte ratio in patients with operable colorectal cancer. Biomarkers. 2012;17:216-22.

11. Krenn-Pilko S, Langsenlehner U, Thurner EM, et al. The elevated preoperative platelet-to-lymphocyte ratio predicts poor prognosis in breast cancer patients. $\mathrm{Br} \mathrm{J}$ Cancer. 2014;110:2524-30.

12. Egan K, Crowley D, Smyth P, et al. Platelet adhesion and degranulation induce pro survival and pro angiogenic signalling in ovarian cancer cells. PLoS One. 2011;6:e26125.

13. Tsuruo T, Fujita N. Platelet aggregation in the formation of tumor metastasis. Proc Jpn Acad Ser B Phys Biol Sci. 2008;84:189-98.

14. Seretis C, Seretis F, Lagoudianakis E, et al. Enhancing the accuracy of platelet to lymphocyte ratio after adjustment for large platelet count: a pilot study in breast cancer patients. Int J Surg Oncol. 2012;2012:603-8.

15. Inagaki N, Kibata K, Tamaki T, et al. Prognostic impact of the mean platelet volume/platelet count ratio in terms of survival in advanced non-small cell lung cancer. Lung Cancer. 2014;83:97-101.

16. Kumagai S, Tokuno J, Ueda Y, et al. Prognostic significance of preoperative mean platelet volume in resected nonsmall-cell lung cancer. Mol Clin Oncol. 2015;3:197-201.

17. Oncel M, Kiyici A, Oncel M, et al. Evaluation of Platelet Indices in Lung Cancer Patients. Asian Pac J Cancer Prev. 2015;16:7599-602.

18. Mutlu H, Artis TA, Erden A, Akca Z. Alteration in Mean Platelet Volume and Platicrit Values in Patients With Cancer That Developed Thrombosis. Clin Appl Thromb Hemost. 2013;19:331-3.

19. Aksoy S, Kilickap S, Hayran M, et al. Platelet size has diagnostic predictive value for bone marrow metastasis in patients with solid tumors. Int J Lab Hematol. 2008;30:214-9.

20. Eryilmaz A, Basal Y, Omurlu IK. Can Head and Neck Cancers Be Detected with Mean Platelet Volume? Asian Pac J Cancer Prev. 2015;16:7045-7. 